\title{
LA DOTACIÓN ARTÍSTICA DE LA CAPILLA DE LA ENCARNACIÓN DE LA CATEDRAL DE SEVILLA ${ }^{1}$
}

\author{
Lina MaLo LaRA \\ Universidad de Sevilla \\ linamalo@us.es
}

\begin{abstract}
Se documenta y estudia la dotación artística de una capilla que perteneció al caballero veinticuatro Juan Serón Olarte y a su esposa doña Antonia de Verástegui, miembros de la élite social sevillana enriquecida gracias al comercio con América. En ella intervinieron, entre 1636 y 1638, destacados creadores como Martín Moreno, Francisco de Ocampo y Baltasar Quintero, junto al menos conocido Juan de Palacios. Su retablo evidencia la pervivencia del manierismo de origen italiano en el arte sevillano de las primeras décadas del siglo XVII, circunstancia en la que jugaría un importante papel la asimilación de diversas fuentes grabadas.

Palabras clave: Catedral de Sevilla; siglo XVII; reja; retablo escultórico; Martín Moreno; Francisco de Ocampo; Baltasar Quintero; Juan de Palacios.
\end{abstract}

\section{THE ARTISTIC ENDOWMENT OF THE INCARNATION CHAPEL IN THE CATHEDRAL OF SEVILLE}

The author documents and studies the artistic endowment of a chapel that belonged to knight Twenty-Four, Juan Serón Olarte, and his wife, Antonia de Verástegui, members of the Sevillian social elite, enriched thanks to the American trade. Between 1636 and 1638 several prominent artists such as Martín Moreno, Francisco de Ocampo and Baltasar Quintero, as well as the lesser known Juan de Palacios, took part in this project. The altarpiece in this chapel reflects the continuing influence of Italian Mannerism in Sevillian art of the early seventeenth century, a circumstance largely determined by the assimilation of diverse engraved sources.

Key words: Cathedral of Seville; $17^{\text {th }}$ century; screen; sculptural altarpiece; Martín Moreno; Francisco de Ocampo; Baltasar Quintero; Juan de Palacios.

A lo largo de los siglos la Magna Hispalensis, centro espiritual y social de la ciudad de Sevilla, representó para sus habitantes, entre otras múltiples significaciones, un anhelado lugar de enterramiento; un colosal panteón del que fueron ambicionadas las distintas capillas que fragmentan su espacio y que singularizan la identidad de los ilustres individuos sepultados en ellas. Entre estos recintos, integradas en los costados del coro de la catedral, se localizan las cuatro pequeñas "capillas de los alabastros", denominadas así tradicionalmente por el material con el que fueron construidas. Entre ellas se encuentra la capilla de la Encarnación, situada en el lado de la epístola del templo, junto al altar presidido por la conocida Inmaculada Concepción de Juan Martínez

\footnotetext{
${ }^{1}$ Agradezco al Excmo. Cabildo de la Catedral de Sevilla, a la Institución Colombina y al Archivo Histórico Provincial de Sevilla las facilidades prestadas para la realización de este trabajo.
} 
Montañés. Ambos espacios arquitectónicos, que fueron trazados por Juan Gil de Hontañón y se adscriben al gótico tardío, se levantaron entre 1515 y $1518^{2}$.

La identidad de los patronos que dotaron la capilla de la Encarnación en el siglo XVII, el caballero veinticuatro Juan Serón Olarte y su esposa doña Antonia de Verástegui, ha sido siempre notoria gracias a la inscripción que recorre su reja. Fue este miembro del consistorio sevillano, de antepasados vascos, un destacado comprador de plata y oro con América, vinculado a una notable familia que debió facilitarle su ascenso social ${ }^{3}$. Así, el padre de su esposa, un hidalgo y rico jurado de Sevilla llamado Pedro López de Verástegui, fue sobrino de un canónigo de la catedral que había adquirido tiempo atrás la capilla que nos ocupa ${ }^{4}$. Nos encontramos, de este modo, ante un matrimonio integrante de aquella antigua élite social, ligada tanto al comercio americano como al gobierno de la ciudad y a las altas esferas eclesiásticas, que tantos testimonios legaría de su privilegiada existencia mediante la dotación de sus recintos funerarios.

Fue el 7 de diciembre de 1635 cuando el cabildo metropolitano, ante "la mucha devoción por la santa iglesia catedral" manifestada por Juan Serón, adjudicó a los esposos esta capilla por la considerable suma de dos mil ducados de plata doble. Quedó entonces el matrimonio obligado a sufragar una bóveda de enterramiento, así como a proveer una reja que fuera similar a la que cercaba el paredaño altar de la Inmaculada. Debía esta pieza ser de su mismo tamaño y vuelo y tener sus "balaustres torneados", pudiendo poner en ella "sus nombres y armas de los dos, marido y mujer". Ambos se comprometieron, asimismo, a encargar un retablo que debía ser de escultura, "con comunicación y parecer de los señores mayordomo y contador de fábrica".

A pesar del interés de las obras de arte que enriquecerían desde entonces la capilla de la Encarnación, es un conjunto que en líneas generales no ha despertado la atención que han merecido otros recintos de la catedral de Sevilla. En este sentido, puede resultar sorprendente que haya permanecido completamente ignorada una antigua publicación que dio cuenta de la autoría de dichas obras. Bien es cierto que en este hecho ha debido influir la circunstancia de estar incluida en una revista sin carácter científico alguno, en la que Santiago Montoto reveló, brevemente y de forma parcial, documentos conservados en el archivo privado de los descendientes de los antiguos patronos (los marqueses de Monsalud) que demostraban que Juan de Palacios, Martín Moreno, Francisco de Ocampo y Baltasar Quintero habían sido, respectivamente, los artífices de la reja, del re-

\footnotetext{
2 Falcón Márquez, 1980: 64-65; 1984: 152. Morales Martínez, 1984a: 179. Rodríguez Estévez, 2007: 173.

${ }^{3}$ Vila Vilar, 2002: 179, 189 (nota 75). Otazu, 2008: 163-170.

${ }^{4}$ Vila Vilar /Lohmann Villena, 2003: 112, nota 399.

${ }^{5}$ Archivo Histórico Provincial de Sevilla. Sección de Protocolos Notariales de Sevilla (AHPSe. SPNSe). Oficio 19. Escribanía de Alonso de Alarcón. Legajo 12.847, fol. 490 r.-494 vto. La venta fue realizada por el canónigo don Fernando de Quesada y el racionero Juan Mateos Álvarez, en virtud de un poder concedido por don Baltasar de Salablanca, arcediano de Niebla y canónigo secretario, fechado el 28 de noviembre de 1635 . Recoge el documento información precisa sobre la bóveda sepulcral, que debía tener la anchura de la reja y de profundidad dos varas y media. A ella podrían trasladar los huesos del licenciado Francisco Serón y de doña María Serón, hermanos difuntos del veinticuatro. Gracias a la información contenida en el testamento firmado por Juan Serón en 1636, se sabe que ya entonces se encontraba labrada la bóveda. Vila Vilar/Kuethe, 2006: 220. La lápida sepulcral que figura en el exterior de la capilla presentaba en origen una inscripción relativa a su patronato, que recoge González de León, ed. 1973: 301. En el acto de adjudicación el matrimonio fundó también una capellanía, que se vio beneficiada con el privilegio de que sus sacerdotes pudieran tomar sus vestiduras en este recinto, no teniendo la obligación de hacerlo en la sacristía de la catedral. Años después doña Antonia de Verástegui instituiría en su testamento, fechado el 27 de septiembre de 1641, la dotación de una memoria perpetua de misas rezadas ligada a esta capellanía, dejando para ello 300 ducados de renta al año. Archivo de la Catedral de Sevilla (ACS). Fondo Histórico General. Sección IX. Legajo 11.278, expediente 43. Algunos datos de la venta de la capilla están recogidos en un documento de 1744 que fue dado a conocer por Quiles: una reclamación del cabildo al entonces heredero del patronato, Juan Flores Olarte, para que pagase un reparo realizado en la reja del recinto. ACS. Secretaría. Autos Capitulares. Legajo 07163, fol. 196 vto.-198 r. Quiles García, 2007: 291-292 (nota 1411).
} 
tablo y sus esculturas y de la policromía y dorado de todo el conjunto ${ }^{6}$. Localizada ahora la documentación de estas obras en el Archivo Histórico Provincial de Sevilla, nos proponemos rescatar del olvido sus autorías, así como analizar unas creaciones que han permanecido bajo el anonimato para la comunidad científica; a excepción de las esculturas del retablo, que fueron certeramente vinculadas a Francisco de Ocampo por Hernández Díaz

Desde la fecha de adjudicación de su capilla, Juan Serón tardó poco más de un mes en formalizar un contrato para proveerla de una reja que la protegiese, la embelleciera y contribuyese a propagar la identidad de sus nuevos dueños. Así, el 16 de enero de 1636 encargó tal menester al maestro herrero Juan de Palacios, vecino de Guadalcanal estante en Sevilla ${ }^{8}$. Conocer la identidad y procedencia de este artífice, del que se poseen muy pocos datos, resulta interesante pues constituye un ejemplo más de la frecuente recurrencia a herreros foráneos para forjar las rejas de la catedral de Sevilla ${ }^{9}$, dado que debían ser aún escasos los maestros locales que trabajaban la rejería artística $^{10}$.

En el concierto de la obra se alude a su destino como "la capilla de los alabastros que es del santo cristo de la columna y ahora ha de ser de la Encarnación de Nuestro Señor" "'. Esta nueva advocación bien pudo responder a una especial devoción profesada a dicho misterio por los patronos, encontrándose muy arraigada, por lo demás, en una Sevilla de marcado fervor mariano. No obstante, pudo también haber sido orientada por el cabildo, en un deseo de conectar iconográficamente esta capilla con la adyacente de la Inmaculada Concepción. En este sentido, debemos recordar que se condicionó expresamente en la adjudicación del recinto el carácter escultórico de su retablo, así como la morfología de su reja, debiendo tomar como modelo la del altar vecino. Dada esta imposición, consta que Juan de Palacios aportó una traza basada en dicho referente. Pero su obra, como ya fuera advertido, deriva en última instancia de la reja de otra de las capillas de alabastro, la de la Virgen de la Estrella, ubicada en el lado del evangelio. Es ésta una pieza de 1568, diseñada por Hernán Ruiz II y Cosme de Sorribas y ejecutada por Pedro Delgado, que sirvió de modelo para las tres rejas que ya en la primera mitad del siglo XVII cerraron las restantes capillas del coro, siendo éste el motivo por el que exhiben formas retardatarias: balaustres, motivos decorativos renacentistas y abundantes labores en chapa repujada ${ }^{12}$. Nos encontramos, sin duda, ante una imposición del cabildo para lograr una deseada uniformidad estética en este espacio de la catedral, dotándolo de un conjunto de rejas que se encuentran también conectadas iconográficamente mediante las figuras femeninas que, recostadas sobre los medios puntos de las puertas de acceso, simbolizan diferentes virtudes.

La reja de la Inmaculada sigue más fielmente el modelo de la capilla de la Virgen de la Estrella, resultando algo más libre la recreación de motivos compositivos y ornamentales en la pieza de la Encarnación (fig. 1). Ésta, a diferencia de las anteriores, no comparte el orden corintio de sus barrotes abalaustrados, ni el mismo tipo de friso recorrido por mascarones, seres fantásticos y escu-

${ }^{6}$ Montoto de Sedas, 1955: 25.

7 Hernández Díaz, 1984, pp. 284, 290-291.

8 AHPSe. SPNSe. Oficio 19. Escribanía de Alonso de Alarcón. Legajo 12.848, fol. 345 r.-348 vto.

9 Morales Martínez, 1984b: 557. Mata Torres, 2001. Quiles García, 2007: 368-370.

${ }^{10}$ Palacios procedía de la sierra norte de la actual provincia sevillana, una región rica en hierro que experimentó el desarrollo de actividades siderúrgicas. Dependiente entonces Guadalcanal en lo civil y en lo eclesiástico de la Orden de Santiago, hubo de trabajar sobre todo en localidades pertenecientes al provisorato extremeño de San Marcos de León. Así, se sabe que participó en 1627 en la reforma de la desaparecida reja de la capilla mayor de la iglesia de Nuestra Señora de la Granada de Llerena. Tejada Vizuete, 1986: 807. Agradezco estas referencias a mi compañero el profesor Antonio J. Santos Márquez.

${ }^{11}$ La antigua advocación era algo ya conocido, sabiéndose que esta capilla estuvo presidida hasta entonces por una imagen de Cristo atado a la columna atribuida a Pedro Millán. Gestoso y Pérez, José, 1890: 277. Pérez Embid, $1973: 62$.

${ }_{12}$ Morales Martínez, 1984b: 563, 565-566. Mata Torres, 2001: 305-307. 


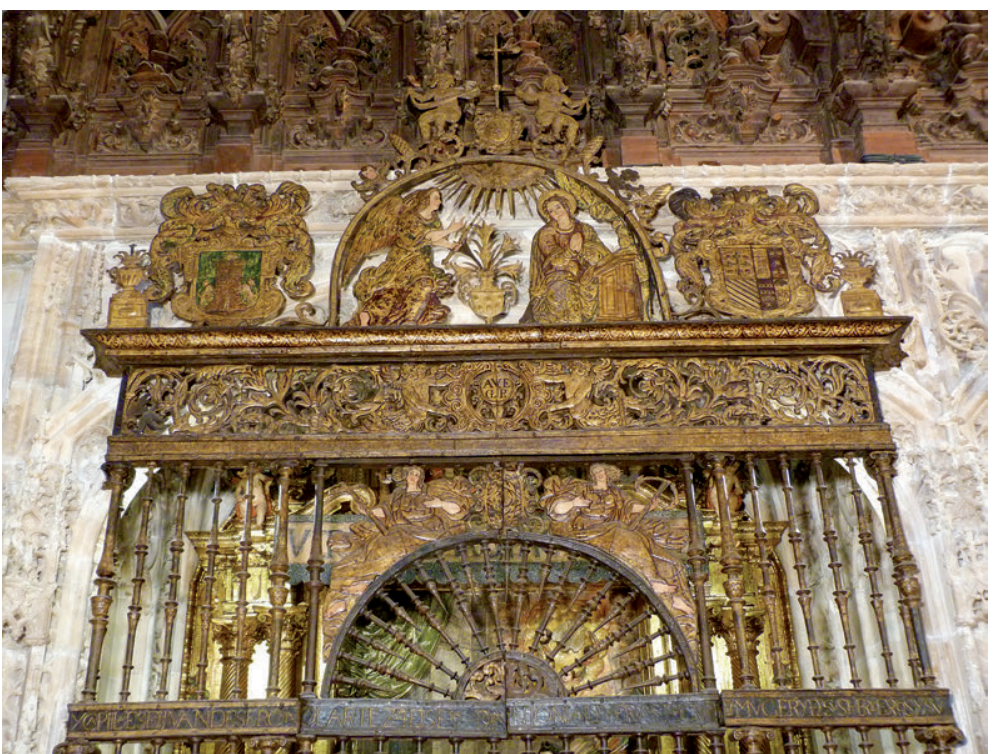

Fig. 1. Juan de Palacios y Baltasar Quintero. Reja de la capilla de la Encarnación. 1636-1638. Catedral de Sevilla. (Fuente: autora).

dos. Se trata de una pantalla estructurada en basamento, dos cuerpos y tres calles, rematada por friso y coronamiento, cuyos barrotes principales se rematan con delgados capiteles jónicos. Los soportes del primer cuerpo exhiben una ornamentación de carácter renaciente, con cintas y hojas enroscadas en su tercio inferior y máscaras femeninas en sus nudos. A lo largo del friso que separa los dos cuerpos se desarrolla la inscripción que proclama el patronazgo de la capilla ${ }^{13}$. Sobre el medio punto de la puerta se disponen reclinadas las figuras de dos virtudes teologales: a la izquierda, portando una cruz, la Fe; a la derecha, la Esperanza, identificable gracias al ancla que sostiene. El friso calado que cierra la estructura se encuentra recorrido por labor de grutesco; en su centro, sosteniendo una cartela en la que se lee una inscripción abreviada alusiva al misterio de la Encarnación ("AVE / GR"), se sitúan simétricamente dos ángeles con la parte inferior del cuerpo metamorfoseada en roleos vegetales. Por último, coronan la reja diversos relieves trabajados en chapa metálica: en el centro compositivo, la Encarnación del Señor, que anticipa el que será el asunto principal del retablo; sobre el medio punto que ciñe dicho tema, unos putti flanquean una cartela que encierra la fecha de $1637^{14}$; finalmente, pregonando el linaje de los patronos, se alzan en los extremos sus escudos de armas, timbrados por yelmos y lambrequines ${ }^{15}$.

13 "Esta bóveda y capilla es de Jvan de Seron Olarte 24 de Sevilla y Doña Antonia de Verastegvi sv mvger y de svs herederos y suzesores".

${ }^{14}$ Palacios se comprometió a comenzar su obra el 8 de febrero de 1636 y a entregarla a finales de agosto de dicho año, pero no debió concluirla en el plazo convenido, ya que el 16 de febrero de 1637 firmó un pago "por cuenta de lo que monta la reja que estoy haciendo", por un importe de 4.391 reales en moneda de vellón. AHPSe. SPNSe. Oficio 19. Escribanía de Alonso de Alarcón. Legajo 12.854, fol. 650 r.-vto. En este documento Palacios aparece avecindado en Sevilla "en Santa María fuera de la Puerta de la Carne". La condición recogida en el contrato de tener que realizar su trabajo en la capital le llevaría a instalarse en una zona de arrabal donde radicaban establecimientos de fundición. Montoto dio a conocer la cifra total a la que ascendió su obra: 19.702 reales, recibiendo el autor una demasía de 2.259 reales debido a la satisfacción de Serón con su trabajo. Montoto de Sedas, 1955: 25.

${ }^{15}$ El escudo de la izquierda, según se contempla la reja, corresponde al apellido Verástegui, vinculado a una noble casa guipuzcoana. El blasón compañero muestra entre sus diversas armas dos de ellas asociadas al apellido Olarte, oriundo 
Traspasando el umbral de la capilla nos encontramos con su retablo, un ejemplar que se venía fechando hacia 1630-1635 y en el que se había advertido la influencia de la "manera" definida en Sevilla por Juan Martínez Montañés ${ }^{16}$. Convertida casi en norma que se prolongó hasta los años centrales del siglo XVII, incidiría en la obra de diversos arquitectos de retablos, entre los que se cuentan Luis de Figueroa, Matías Fernández Cardoso o Martín Moreno ${ }^{17}$. Precisamente la escritura de su concierto, fechada el 14 de junio de 1637, revela que fue Martín Moreno el autor responsable de su traza, talla y ensamblaje ${ }^{18}$. Es este maestro († c.1677) un arquitecto de retablos sobre el que se han realizado en los últimos años aportaciones que permiten un mejor conocimiento de su figura ${ }^{19}$. En ellas se ha puesto de relieve el tradicional lugar secundario al que se ha visto desplazado en comparación con otros artistas, reclamándose una mayor atención sobre su obra, que desarrolló de forma intensa en la diócesis de Sevilla, trabajando para importantes comitentes. Comenzó realizando el ensamblaje de obras trazadas por otros maestros, dentro de un lenguaje clasicista, como el retablo para la capilla del poeta Francisco de Rioja en el convento sevillano de San José del Carmen (1627), en el que seguiría un diseño de Montañés ${ }^{20}$. En su ascendente trayectoria profesional, ya como maestro tracista de sus propias obras, un encargo clave hubo de ser el recibido en 1637 del veinticuatro Serón para su capilla en la catedral; lugar reservado, como es sabido, para los mejores artistas, suponía un espaldarazo para aquellos que lograban trabajar en él. En este sentido, quizás la obra que tratamos le sirviera de carta de presentación ante don Gonzalo Núñez de Sepúlveda, patrono de la capilla de la Concepción Grande del templo metropolitano para la que Moreno realizaría también su retablo, a partir de $1655^{21}$. Evolucionó su autor en esta destacada obra hacia planteamientos barrocos, contándose entre los primeros ejemplares sevillanos que asentarían el uso de la columna salomónica. Tras el éxito que le supuso esta gran máquina lignaria, recurriría a él influyente canónigo don Justino de Neve para diseñar el retablo mayor de la parroquia sevillana de Santa Maria la Blanca ${ }^{22}$.

Retomando el conjunto que nos ocupa, Moreno se comprometió a realizarlo según una traza propia cuyas condiciones, muy detalladas en el contrato, el artista siguió fielmente. Ceñiría el cuerpo principal con dos columnas enteras y dos medias columnas con basas, fustes torneados y capiteles corintios de hojas arpadas. Dadas las reducidas dimensiones de la capilla y, consecuentemente, de su retablo, se comprende la preocupación manifestada en el concierto porque sus imágenes principales, dedicadas al misterio de la Encarnación, lucieran convenientemente. En este sentido, se acordó que pudiera aumentarse en altura la caja central respecto a lo convenido inicial-

de Vizcaya: una cruz flordelisada y una encina con dos lobos trepantes. Origen también vizcaíno posee el apellido Serón, cuyas armas tradicionales no encontramos sin embargo en este escudo. García Carraffa, t. XVI: 50-51, t. LXIII: 212-213, t. LXXXIV: 107-108.

16 Villar Movellán, 1977: 65-67. Guerrero Lovillo, 1981: 122. Hernández Díaz, 1984: 290. Morales et alt., 2004: 63.

${ }^{17}$ Palomero Páramo, 1983: 391 y ss. Halcón, 2009a: 129-202.

${ }_{18}$ AHPSe. SPNSe. Oficio 19. Escribanía de Alonso de Alarcón. Legajo 12.856, fols. 483 r.-485 r. Vecino de la collación de San Andrés, fue su fiador el carpintero Alonso de Mendoza.

${ }^{19}$ Halcón/Herrera/Recio, 2000: 91, 239, 492 y 522. Illán/Valdivieso, 2005: 122-123. Halcón, 2009b: 211-213. Falcón Márquez, 2013: 69-87.

${ }^{20}$ Malo Lara, 2008-2009: 395-409.

${ }^{21}$ Tuvo este patrono un perfil afín al de Serón, siendo posible que ambos se conocieran, pues fue también un rico comerciante ennoblecido que, en 1635, desempeñaba el cargo de veinticuatro de la ciudad. A pesar de esta conexión, es cierto que mediaron casi veinte años desde que Moreno hiciera el retablo de la Encarnación hasta que los albaceas del entonces difunto patrono le encomendaran el conjunto de la Concepción. Sobre Núñez de Sepúlveda y su capilla: De la Campa y Carmona, 2003: 425-448. Quiles García, 2007: 292-293. Falcón Márquez, 2013: 74-80.

${ }^{22}$ Halcón, 2000: 239-240. Quiles García, 2007: 344. Halcón, 2009b: 211-213; Falcón Márquez, 2013: 74-87. 


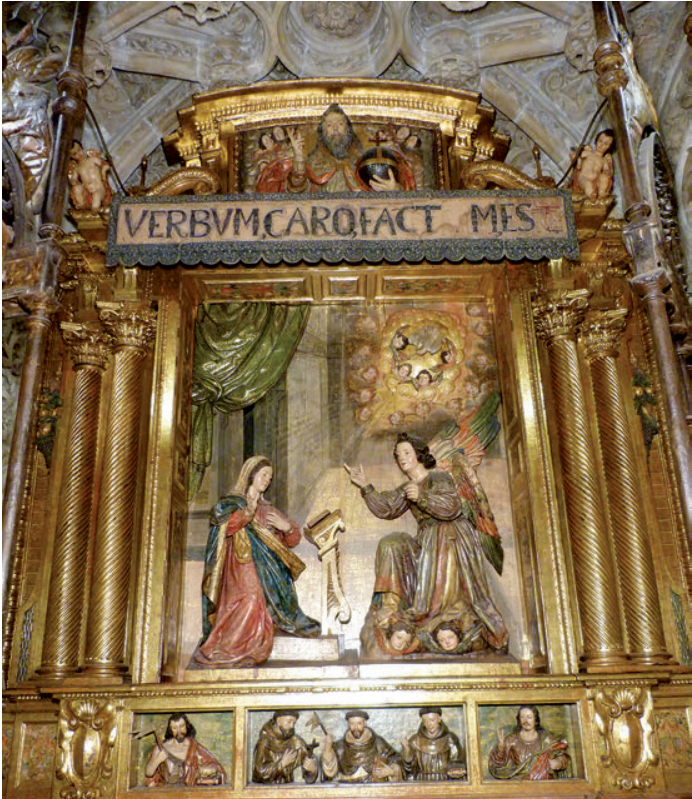

Fig. 2. Martín Moreno, Francisco de Ocampo y Baltasar Quintero. Retablo de la capilla de la Encarnación. 1637-1638. Catedral de Sevilla. (Fuente: autora).

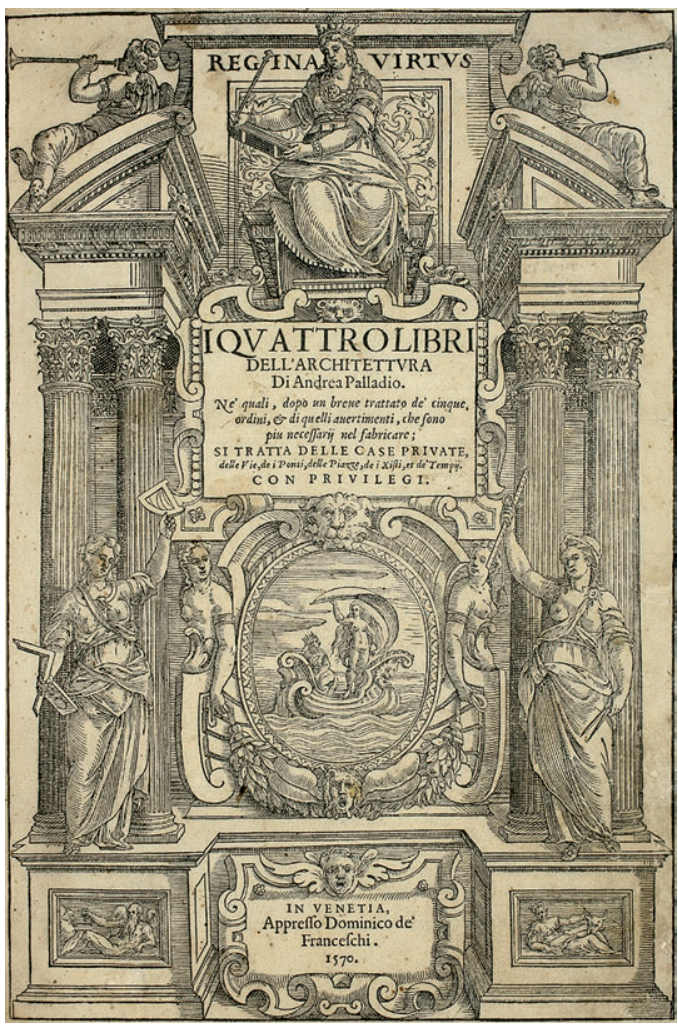

Fig. 3. Andrea Palladio. I quattro libri dell'Archittetura. Venecia, 1570.

mente "para desahogo de la historia y mejor proporción" 23 . Se indicaron también a Moreno los asuntos que debían ocupar los restantes tableros escultóricos: en el ático, un Dios Padre; y en el banco "los santos que Juan Serón tuviere devoción". Finalmente se precisaron cuestiones referentes al ornato del retablo, como los "agallones, cuentas y óvalos" que debían enriquecer la moldura de la caja principal, o los óvalos y saetillas que debían recorrer la moldura que guarnecería el testero de la capilla. Por todo su trabajo, que debía realizar en madera de borne en un plazo de seis meses, percibiría trescientos veinte ducados en moneda de vellón ${ }^{24}$.

Martín Moreno diseñaría un conjunto (fig. 2) que se adscribe a la tipología comunmente denominada retablo-tabernáculo; un sencillo esquema arquitectónico dotado de banco, un cuerpo con una gran caja para la escena principal, y un ático de reducidas dimensiones, enmarcado aquí por un frontón partido y curvo coronado con esculturas. Conocido es que ésta fue una solución de

${ }^{23}$ La caja debía medir dos varas y media de alto por dos varas y sesma de ancho, y su profundidad no debía ser inferior a media vara (unos 2,08 x 1,80 x 0,41 m.). Finalmente se conseguiría aumentar estas dimensiones, pues mide aproximadamente $2,22 \times 1,82 \times 0,49 \mathrm{~m}$.

${ }^{24}$ Recibiría esta cantidad según costumbre, en tres pagos. En ella entraban también dos pequeñas cajoneras de madera de borne que se dispondrían en los laterales de la capilla para albergar las vestiduras y ornamentos necesarios para la capellanía fundada por los patronos. Son muebles que no se conservan en la actualidad. Montoto aportó el dato de que el 19 de julio de 1638 Moreno firmó el finiquito de este encargo. Montoto de Sedas, 1955: 25. 
larga tradición en la retablística sevillana desde las formulaciones de Jerónimo Hernández y Juan Martínez Montañés sobre el difundido frontispicio de la edición veneciana de I quattro libri dell'Archittetura de Andrea Palladio (fig. 3) y otros modelos de la tratadística italiana del Manieris$\mathrm{mo}^{25}$. Diseñaría Montañés numerosos tabernáculos, como la estructura interna del retablo del poeta Francisco de Rioja que comentamos ensambló Moreno en 1627. Dicha circunstancia le haría conocedor de primera mano de esta recurrente estructura compositiva, que años más tarde aplicaría para trazar el conjunto de la Encarnación, que resulta próximo al frontispicio palladiano.

El cuerpo principal de este retablo queda delimitado por dos pares de columnas y medias columnas corintias que apean sobre sendos pedestales tachonados con tarjas coronadas por veneras, decoradas en su interior con motivos vegetales estofados. La hermosa caja central, rematada en codillos, se ciñe con un marco recorrido por molduras de hojas y óvalos. Es notable su profundidad, que se aprovechó para enriquecer sus laterales y techo con un cajeado decorado con motivos vegetales estofados a punta de pincel. Sirve de respaldo al retablo un muro que simula un aparejo de sillares, solución ésta utilizada en Sevilla por autores como Jerónimo Velázquez o los hermanos Ribas en sus obras y que usará también Moreno en conjuntos posteriores. Para conectar el cuerpo principal con dicho respaldo, utiliza aquí el artista unos "arbotantes" -así son denominados en el contrato- que remata con guirnaldas de frutas y decora en su parte inferior con hojas de laurel. El entablamento resulta poco perceptible pues quedó oculto, en fecha que descococemos, por una colgadura de tela con aplicaciones de plata que reproducen una inscripción alusiva al misterio de la Encarnación ${ }^{26}$. Su cornisa se rompe y curva, dando lugar a unas volutas decoradas con hojas que enmarcan el pequeño ático de remate; en sus extremos, se disponen unos angelotes, apareciendo también como elementos ornamentales jarrones coronados por agujas.

Todo este repertorio formal y decorativo se encuadra dentro de la tradición tardo renacentista perpetuada por Montañés y sus seguidores, sin que se adviertan en este retablo signos de la más turgente ornamentación que por estos años un autor como Alonso Cano introducía en sus obras sevillanas. En este sentido, tendría que pasar más tiempo para que Moreno desarrollase una plasticidad barroca en los elementos compositivos y ornamentales de sus trabajos; así, por ejemplo, las abultadas tarjas, las columnas salomónicas y las impetuosas volutas de los frontones del aludido retablo de la Concepción Grande de la catedral.

En cuanto a las esculturas del conjunto diversos historiadores destacaron su calidad, singularmente la de sus imágenes principales, trabajadas "con inteligencia del arte" a decir de Ceán Bermúdez ${ }^{27}$. Y también llamaron la atención sobre su carácter montañesino, siendo en ocasiones su imaginería atribuida a la gubia del maestro alcalaíno ${ }^{28}$. Sería el profesor Hernández Díaz quien las vinculara por afinidades estilísticas al quehacer de Francisco de Ocampo, formulando una atribución que no encontraría posteriormente eco en los estudios realizados sobre este escultor. Las fechó entre 1630 y $1635^{29}$. El contrato de estas imágenes ${ }^{30}$, datado el 23 de julio de 1637, permite refrendar dicha autoría, así como acrecentar el relativamente reducido catálogo de obras conservadas y seguras del maestro. Se incluye este conjunto entre sus últimas creaciones, pues fallecería en 1639, poco tiempo después de haberlas ejecutado.

${ }^{25}$ Palomero Páramo, 1982: 503-525; 1983: 98, 415. Además de este modelo palladiano se han señalado otras fuentes de inspiración para la tipología del retablo-tabernáculo sevillano, como ventanas y puertas miguelangelescas recogidas por Vignola, así como vanos contenidos en el Tercero y Cuarto Libro de Arquitectura de Serlio: Navarrete Prieto, 2005: 244. Herrera García, 2010: 387-388, 391.

26 "VERBVM CARO FACT(V)M ES(T)" ("El verbo se hizo carne". Jn, 1: 4).

${ }^{27}$ Ceán Bermúdez, ed. 1981: 66.

${ }^{28}$ González de León, ed. 1973: 301. Santos y Olivera, 1930: 80. Montoto de Sedas, 1948: 48. Villar Movellán, 1977: 65-67. Guerrero Lovillo, 1981: 122.

${ }^{29}$ Hernández Díaz, 1984: 284 y 290-291.

${ }^{30}$ AHPSe. SPNSe. Oficio 19. Escribanía de Alonso de Alarcón. Legajo 12.856, fols. 575 r.-576 r. 
Hacía entonces más de cuarenta años que este escultor de origen jiennense había llegado a Sevilla para aprender el oficio junto a su afamado tío, Andrés de Ocampo, continuando posteriormente su formación bajo el magisterio de Juan de Oviedo el Mozo. Trabajaría intensamente al servicio de diferentes clientes, entre los que se cuentan el Arzobispado hispalense, así como distintas órdenes religiosas, hermandades y comitentes particulares, atendiendo también con frecuencia encargos procedentes de Canarias y del mercado americano. El trabajo realizado para Serón fue la primera ocasión -y la única, que se sepa- en la que el maestro tuvo el privilegio de intervenir en la catedral de Sevilla. Cuando realizó este conjunto era ya un autor de avanzada edad -tenía 58 años $-\mathrm{y}$ contaba con una trayectoria profesional consolidada, tras haber realizado destacadas obras. Entre éstas, se encuentran el Nazareno de San Bartolomé de Carmona -obra segura que ha servido de base para atribuirle las imágenes de igual iconografía titulares de las hermandades sevillanas del Silencio y de la Candelaria-, o el Crucificado del Calvario de la parroquia de la Magdalena. Con Martínez Montañés colaboraría en ciertos encargos, influyéndole este maestro en su técnica de talla, así como en determinados rasgos formales, si bien supo Ocampo desarrollar un estilo personal, evolucionando desde el manierismo de su formación inicial hacia un naturalismo de signo barroco, atemperado por la lección del clasicismo ${ }^{31}$.

Para componer las imágenes principales del retablo que nos ocupa (fig. 4) Ocampo siguió fielmente las precisas condiciones recogidas en el contrato sobre ello. Así, dispuso a la Virgen "hincada de ambas rodillas" en el lado del Evangelio, bajo un pabellón, frente a un atril con un libro y junto a una jarra de azucenas ${ }^{32}$. Y situó a San Gabriel "dando la embajada a la Virgen Nuestra Señora sobre un trono de serafines y nubes", mientras en el tablero del respaldo emergía entre ángeles la paloma del Espíritu Santo. Esta composición del misterio de la Encarnación debía realizarla "conforme a el modelo que está hecho de barro", interesante alusión a una extendida práctica entre los escultores a la que el propio Ocampo recurrió en otros encargos ${ }^{33}$. Completando la escena tendría que disponer un Dios Padre en el ático del retablo, junto a cinco santos de medio relieve en el banco, "los que eligiere y dijere Juan Serón". Debía tallar todas las imágenes en madera de cedro, en un plazo de ocho meses - para marzo de 1638- y por precio de trescientos cincuenta ducados ${ }^{34}$.

Bajo estos condicionantes comenzaría el artista a trabajar en su obrador, teniendo que materializar un asunto, el de la Encarnación de Jesucristo, del que no conocemos paralelos en su obra conservada. Para componer esta escena, resulta evidente que Ocampo se inspiró en la conocida estampa abierta por Cornelis Cort en 1571 sobre la Anunciación con los profetas que Federico Zuccaro pintó para la Annunziata de Roma (fig. 5) ${ }^{35}$. Como es sabido, fue ésta una de las fuentes grabadas que ejerció un mayor influjo en el arte español, encontrando en ella tanto pintores como escultores un amplio repertorio de modelos y actitudes ${ }^{36}$. Repiten las esculturas de Ocampo fielmente la disposición y los ademanes de las imágenes del original italiano, siendo más que probable

${ }^{31}$ Sobre este autor: Hernández Díaz, 1980: 93-115. Martín Macías, 1983. Bernales Ballesteros/García de la Concha, 1986: 53 y ss. González Gómez/Roda Peña, 1992: 70-76. García López, 2002: 109-125. Rodríguez Morales, 2010: 467470. Gila Medina/Herrera García, 2010: 528 y ss. Ramos Sosa, 2010: 493-499; 2013: 281-300. Roda Peña, 2013: 167168; 2015, pp. 63-65. Malo Lara, 2015: 54-56.

${ }^{32}$ Estas flores debían ser de bronce y las encargaría el patrono a otro artífice. El jarrón no se conserva hoy día, siendo probable que se sustrajera, al igual que debió ocurrir con las azucenas que debió portar el arcángel en su mano izquierda, que muestra una base de madera en la que debieron ensamblarse las flores.

${ }_{33}$ Así, en el relieve que centró el desaparecido retablo mayor del convento dominico de la Pasión de Sevilla (1638). Malo Lara, 2003: 421

${ }^{34}$ Ocampo reconoció haber recibido entonces cien ducados, primera paga de las tres acostumbradas. Según Montoto el 29 de julio de 1638 el escultor dio por cancelado este encargo. Montoto de Sedas, 1955: 25.

${ }^{35}$ Strauss/Shimura, 1986: 35.

${ }^{36}$ Navarrete Prieto, 1998: 53; 2008: 159-168. García Luque, 2013: 179-256. 


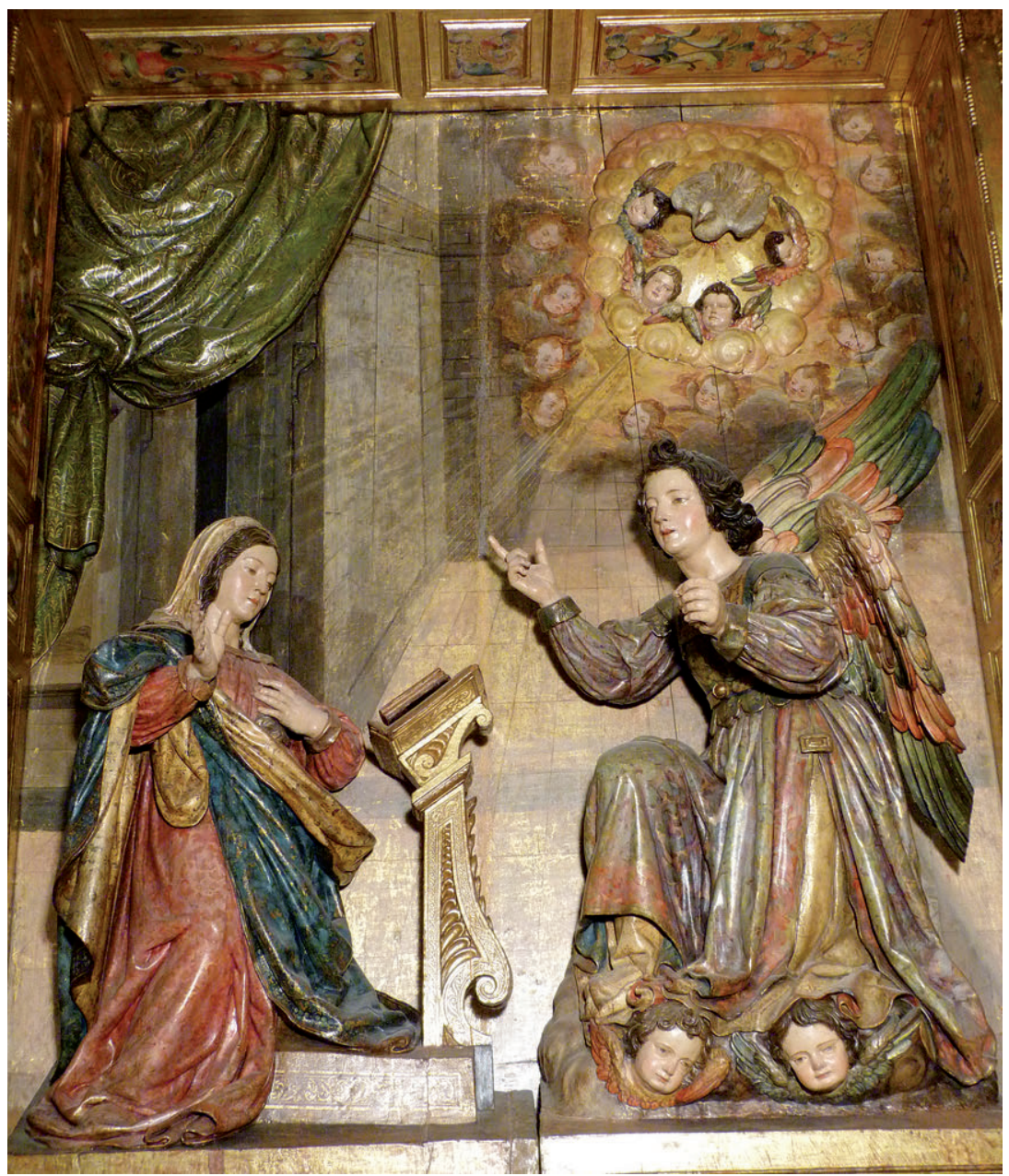

Fig. 4. Francisco de Ocampo y Baltasar Quintero. La Encarnación de Jesucristo. (Fuente: autora).

que el grabado de Cort que lo reprodujo figurase en la extensísima colección de estampas que poseyó su tío Andrés y que heredaría en gran parte Francisco ${ }^{37}$. No en vano puede advertirse cómo el mayor de los Ocampo siguió también este referente en el relieve de la Anunciación del retablo mayor de la parroquia gaditana de Santa María en Arcos de la Frontera (1586-1587) (fig. 6) ${ }^{38}$. Lo haría de una forma menos literal que Francisco; compárense, en este sentido, aspectos como la indumentaria del ángel, la disposición de sus alas o de su brazo izquierdo.

Fue esta composición de Zuccaro, por otra parte, especialmente recomendada en el medio artístico sevillano por Francisco Pacheco, quien en su Arte de la pintura la menciona como modelo a seguir para plasmar el episodio de la Anunciación. Y es que en ella el ángel se mostraba "con decoro y majestad", requisitos que tan fundamentales resultaban para este veedor de imágenes sagradas, y no "muy desnudo" como ocurría en otros referentes de Miguel Ángel o de Tiziano ${ }^{39}$.

${ }^{37}$ Sobre la colección de grabados y la biblioteca de Andrés de Ocampo: Bago y Quintanilla, 1928: 41 y 47. Martín Macías, 1983: 70-73. Hernández Díaz, 1987a: 30-36. González Sánchez, 2012: 54-59. García Luque, 2013: 195.

${ }^{38}$ Hernández Díaz, 1987a: 62 y 122-123.

39 Pacheco, ed. 2001: 594. 


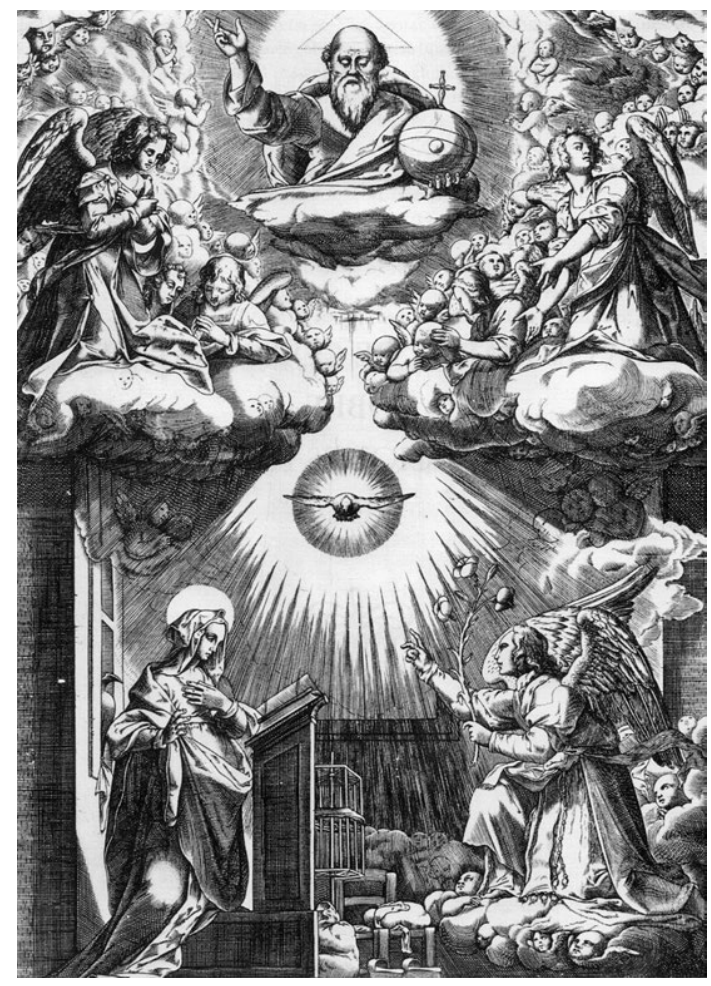

Fig. 5. Cornelis Cort, Anunciación con los profetas que predijeron la venida del Mesías (detalle), 1571, grabado sobre composición de Federico Zuccaro.

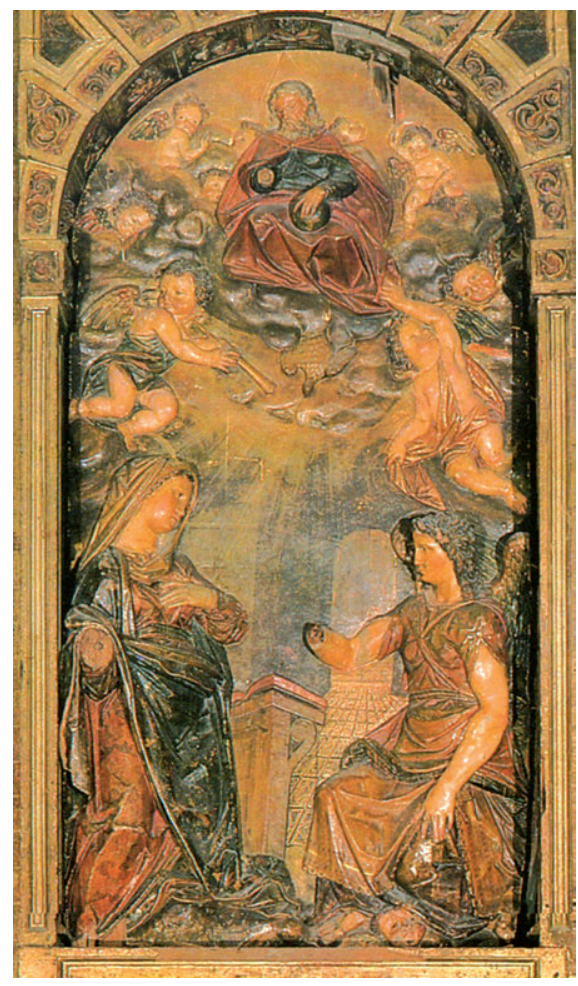

Figura 6. Andrés de Ocampo. Anunciación. 1586-1587. Retablo mayor de la parroquia de Santa María de Arcos de la Frontera (Cádiz).

Mencionaría Pacheco en su tratado el frecuente uso de estampas por parte de los escultores, ejemplificando la recurrencia a originales de los hermanos Zuccaro en el ámbito local ${ }^{40}$. Aunque el pintor se refiriera al respecto, expresamente, a Diego de Pesquera y a Juan Bautista Vázquez el Viejo, bien pudo contemplar otros ejemplos, como el grupo de la Encarnación de la catedral. En tal caso, debió aprobar, sin duda, cómo había representado Ocampo este asunto, siguiendo el grabado de Cort y coincidiendo con sus recomendaciones ${ }^{41}$. Pero es difícil saber si Pacheco, quien colaboró con el escultor en obras comunes, pudo haber influido, de algún modo, en la configuración iconográfica de estas imágenes ${ }^{42}$.

Se insertan los protagonistas de este episodio en un escenario en el que se advierten ligeras diferencias respecto a la fuente original: así, el cortinaje suspendido sobre la Virgen, que se arrodilla frente a un atril de mayor riqueza formal; o la irrupción de la paloma del Espíritu Santo a la derecha del grupo, solución que acentúa la diagonal que lo recorre y que introduce cierto dinamismo respecto a la composición marcadamente triangular del grabado. En el tablero del res-

${ }^{40}$ Pacheco, ed. 2001: 127, nota 41. García Luque, 2013: 181, nota 1.

${ }^{41}$ Pacheco, ed. 2001: 593-594.

${ }^{42}$ Ambos artistas habían trabajado en 1610 en la renovación del retablo de san Juan Bautista del convento de San Clemente de Sevilla. Valdivieso/Serrera, 1985: 49-54. Palomero Páramo, 1983: 388-390. Y en 1638 lo harían en el retablo mayor del convento sevillano de la Pasión. Malo Lara, 2003: 417-425. 


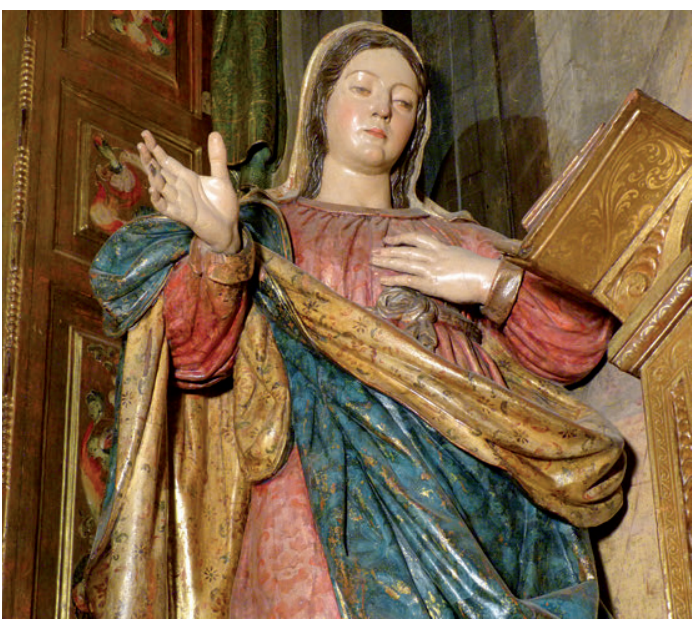

Figs. 7 y 8. Francisco de Ocampo y Baltasar Quintero. Virgen Maria y San Gabriel (detalles). (Fuente: autora).

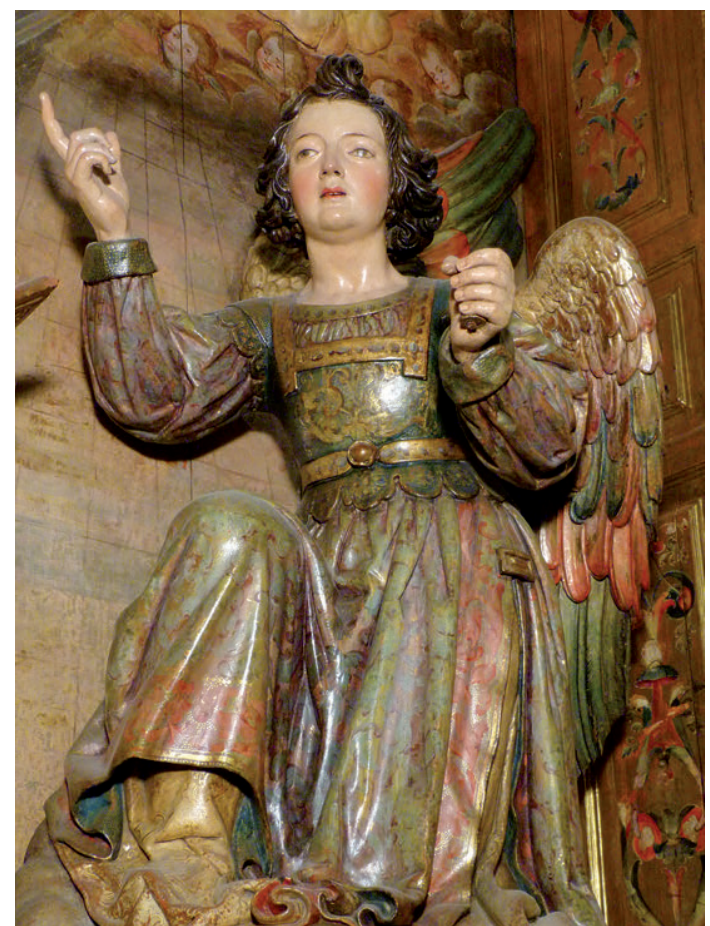

paldo se ensambla una de las alas del arcángel, completando, de esta forma, una imagen que es de bulto redondo, al igual que su compañera. Reposan ambas sobre una ancha base, mostrando gran aplomo y naturalidad. Con la serena y recogida actitud de la Virgen, contrasta la mayor expresividad de san Gabriel en su anuncio del mensaje divino. Sus rostros de clásico perfil resultan de gran belleza y, a pesar de su clara filiación montañesina, muestran rasgos propios de Ocampo (figs. 7 y 8): son rostros anchurosos, de mentón pronunciado, siendo especialmente reveladores sus ojos, de párpados entornados y pupilas que acusan una leve asimetría, rasgo que no es infrecuente encontrar en sus obras. Por otra parte, se advierte en ellas claramente el influjo de Montañés en el tratamiento del cabello, denotando igualmente dicha influencia los ropajes, tallados a base de gruesos pliegues que caen verticalmente. Recoge la Virgen su manto con uno de sus brazos, generando un claro acento diagonal y pliegues de rica plasticidad, que dinamizan su figura y potencian el juego de volúmenes y efectos claroscuristas.

Es de resaltar, también, el hermoso estofado que enriquece las telas de ambas figuras, así como el vistoso cromatismo de las alas del arcángel. De esta labor de policromía y dorado, no sólo del retablo y de sus imágenes, sino también de la reja de la capilla, sabemos que se encargó otro notable artista: Baltasar Quintero. Así consta en la carta de finiquito de 1.800 reales firmada por este pintor el 27 de julio de 1638, por cuenta de los 8.800 reales en que concertó, en fecha desconocida, los citados trabajos $^{43}$. Permite este último documento, además, conocer el más que estimable montante al que ascendió la dotación artística sufragada por el matrimonio Serón-Verástegui ${ }^{44}$.

${ }^{43}$ Se definen en el pago como el "dorado y estofado y encarnado del retablo y dorado de la rexa y todas las demás menudencias”. AHPSe. SPNSe. Oficio 19. Escribanía de Alonso de Alarcón. Legajo 12.860, fol. 546 vto.

${ }^{44}$ La cifra total es de 3.261 ducados, y a ella habría que añadir los 2.000 ducados de plata doble que entregaron por la adquisición de la capilla. 


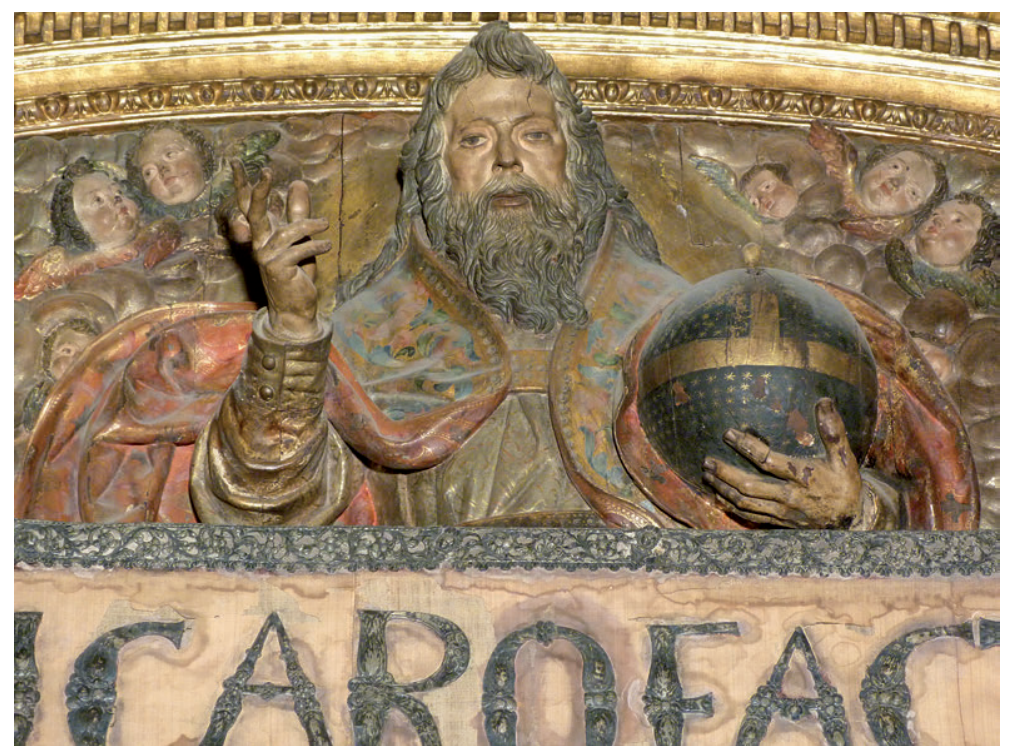

Fig. 9. Francisco de Ocampo y Baltasar Quintero.

Dios Padre. (Fuente: autora).

Gracias a la reciente restauración a la que se ha sometido el conjunto de la capilla, puede apreciarse con justeza la calidad del trabajo de Baltasar Quintero. Fue este maestro asiduo colaborador de Montañés en la policromía de sus esculturas; no en vano fue considerado en su época "pintor de primor... persona muy perita... y el mejor oficial que hoy se conoce de este género de pintura" ${ }^{45}$. Cuando firmó su contrato con Serón, había trabajado ya en el templo metropolitano, realizando junto a Francisco Pacheco la policromía del retablo de la Inmaculada del altar vecino. E, igualmente, había colaborado con Ocampo en trabajos comunes ${ }^{46}$. Comparando las labores de estofado de las imágenes del retablo de la Encarnación con las desplegadas por Quintero en otras obras suyas $^{47}$, se advierten claras similitudes en cuanto a los tipos y a la rica variedad de motivos ornamentales empleados: decoración floral menuda combinada con formas vegetales amplias y carnosas, estofadas a punta de pincel, junto a motivos grabados, fundamentalmente ojeteados y rajados.

El grupo de la Encarnación se completa con la figuración ideada para el ático del retablo, para el que Ocampo talló un alto relieve con una notable figura de Dios Padre (fig. 9). Captado de medio cuerpo en medio de un rompimiento de gloria tachonado con cabezas de querubes, bendice la escena que preside al tiempo que sostiene un orbe. Ocampo lo representó de forma similar al Padre Eterno de la estampa de Cort, introduciendo variantes sobre esta base iconográfica. Así, el tratamiento de la abundante cabellera y de la luenga barba, trabajada en pequeños y dinámicos mechones, o la disposición del manto, de forma envolvente alrededor de ambas manos. El resultado es una imagen enérgica, tratada de modo naturalista, que responde igualmente a los rasgos fisonómicos propios de su autor.

${ }^{45}$ Díaz Hierro, 1965: 307.

${ }^{46}$ Así, en una Inmaculada encargada a Ocampo en 1612 por un particular, en paradero desconocido. Martín Macías, 1983: 149. Y en unos santos del retablo de San Juan Evangelista del convento sevillano de San Leandro (1632-1633) que se vinculan a este escultor. Hernández Díaz, 1987b: 234-238.

${ }^{47}$ Así, la Santa Ana que hizo Montañés para la iglesia de San Alberto de Sevilla, hoy en el Buen Suceso, cuya policromía contrató Quintero en 1633. Malo Lara, 2015: 116-117. 


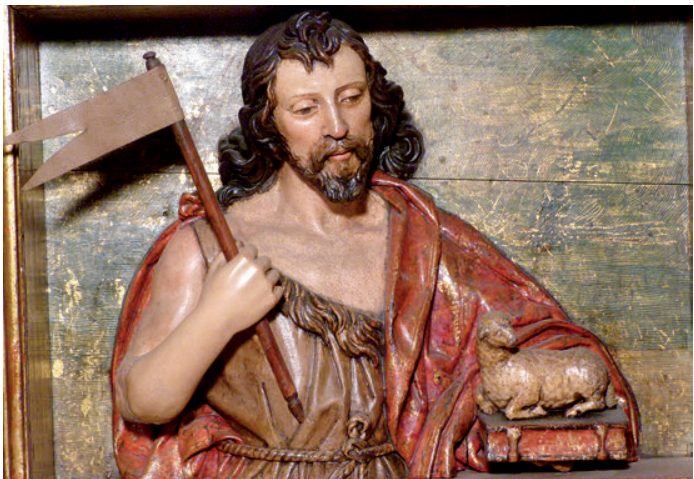

Fig. 10. Francisco de Ocampo y Baltasar Quintero. San Juan Bautista. (Fuente: autora).

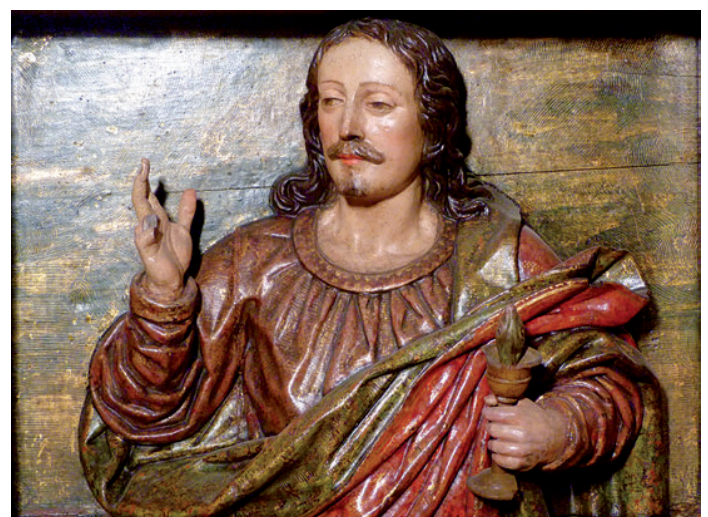

Fig. 11. Francisco de Ocampo y Baltasar Quintero. San Juan Evangelista. (Fuente: autora).

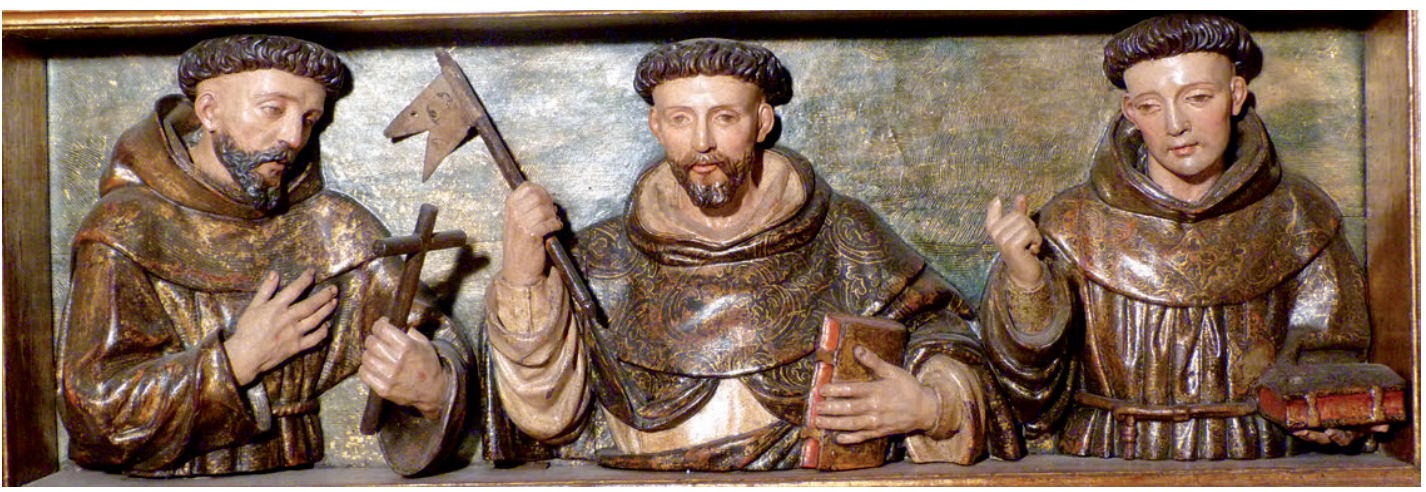

Fig. 12. Francisco de Ocampo y Baltasar Quintero. San Francisco de Asís, Santo Domingo de Guzmán y San Antonio de Padua. (Fuente: autora).

Completan el programa iconográfico las figuras de los cinco santos elegidos por Juan Serón y doña Antonia de Verástegui para el banco. Es evidente que la presencia de los dos santos Juanes y de san Antonio de Padua se explica por ser los patronos de ambos. Junto a ellos, san Francisco de Asís y santo Domingo de Guzmán podrían encarnar también devociones particulares de los comitentes; si bien su aparición conjunta podría vincularse igualmente a la frecuente asociación de ambos santos fundadores en retablos sevillanos consagrados a la Virgen María, singularmente a la Inmaculada. Con ella se recordaba su fervor mariano, al tiempo que se cerraban posibles resquicios derivados de la controversia concepcionista generada años atrás en la ciudad. Todas ellas son figuras de pequeño formato, captadas de medio cuerpo, y talladas en relieve siguiendo sencillos esquemas compositivos. Revelan una clara influencia montañesina, acusando no obstante rasgos propios de su autor; singularmente, los ojos. En los recuadros de los extremos se disponen san Juan Bautista, a la izquierda, y san Juan Evangelista, a la derecha, respondiendo ambos a su tipo iconográfico habitual. El Precursor de Cristo (fig. 10), vestido con piel de camello y manto rojo, porta en sus manos una banderola metálica y un libro sobre el que reposa el Cordero de 
$\operatorname{Dios}^{48}$. El Evangelista (fig. 11), dispuesto en ademán de bendecir, lleva en su mano izquierda un cáliz del que emerge una llama, clara alusión al veneno con el que se le quiso dar muerte ${ }^{49}$. En el hueco central del banco (fig. 12) se sitúan, vestidos con hábito pardo, san Francisco de Asís, absorto en meditación frente a un crucifijo, y san Antonio de Padua, joven imberbe en reflexiva actitud. A juzgar por las marcas existentes sobre el libro que porta este último, debió sustraérsele su atributo identificativo, presumiblemente la figura de un pequeño Niño Jesús. Flanquean ambos la imagen central de santo Domingo de Guzmán, quien, provisto de hábito blanco y capa negra, banderola con el escudo de la orden y libro, se muestra en actitud frontal, dirigiendo su mirada directamente al espectador ${ }^{50}$.

A través de ejemplos como el retablo aquí estudiado puede constatarse, una vez más, la pervivencia del manierismo de estirpe italiana en el arte sevillano de las primeras décadas del siglo XVII, circunstancia en la que desempeñó un papel fundamental la asimilación de fuentes grabadas tan difundidas como las que hemos tenido ocasión de recordar. E igualmente puede advertirse cómo sobre estos modelos creadores notables, tal el caso de Francisco de Ocampo, compusieron unas obras que anunciaban una evolución estilística hacia formas propias del naturalismo barroco.

\section{BIBLIOGRAFÍA}

Bago y Quintanilla, Miguel (1928): “Aportaciones documentales”, en Documentos para la Historia del Arte en Andalucía, t. II. Sevilla: Laboratorio de Arte. Universidad de Sevilla, pp. 33-49.

Bernales Ballesteros, Jorge/García de la Concha Delgado, Federico (1986): Imagineros andaluces de los Siglos de Oro. Sevilla: Editoriales Andaluzas Unidas.

Ceán Bermúdez, Juan A. (1804, ed. 1981): Descripción artística de la Catedral de Sevilla. Sevilla: Renacimiento.

De la Campa y Carmona, Ramón (2003): "Un ejemplo de patronazgo nobiliario en la Catedral de Sevilla: la capilla de la Concepción Grande y don Gonzalo Núñez de Sepúlveda”, en Ramallo Asensio, Germán (coord.): El comportamiento de las catedrales españolas del barroco a los historicismos. Murcia: Universidad de Murcia, pp. 425-448.

Díaz Hierro, Diego (1965): "Baltasar Quintero. Arquitecto de retablos, pintor y escultor, fue este ilustre onubense el compañero predilecto de Martínez Montañés", en Archivo Hispalense, n 134, pp. 303-308.

Falcón Márquez, Teodoro (1980): La Catedral de Sevilla: estudio arquitectónico. Sevilla: Diputación Provincial de Sevilla.

Falcón Márquez, Teodoro (1985): "El edificio gótico", en AA.VV.: La Catedral de Sevilla. Sevilla: Ediciones Guadalquivir, pp. 133-172.

Falcón Márquez, Teodoro (2013): "El arquitecto de retablos Martín Moreno y los primeros retablos con columnas salomónicas en Sevilla", en Boletín de Arte, no 34, pp. 69-87.

García Carraffa, Alberto y Arturo (1920-1963): Enciclopedia heráldica y genealógica hispano-americana, vol. XVI, vol. LXIII, vol. LXXXIV. Madrid: Antonio Marzo.

García López, José L. (2002): Jaén, clave en la escultura de los siglos de oro. Sevilla: Fundación Cruzcampo.

García Luque, Manuel (2013): "Fuentes grabadas y modelos europeos en la escultura barroca andaluza (1600-1650)", en Gila Medina, Lázaro (coord.): La consolidación del barroco en la escultura andaluza e hispanoamericana. Granada: Universidad de Granada, pp. 179-256.

Gestoso y Pérez, José (1890): Sevilla Monumental y Artística: historia y descripción de todos los edificios notables..., t. II. Sevilla: Oficina tipográfica de El Conservador.

Gila Medina, Lázaro/Herrera García, Francisco J. (2010): "Escultores y esculturas en el reino de Nueva Granada (Colombia)", en Gila Medina, Lázaro (coord..): La escultura del primer naturalismo en Andalucía e Hispanoamérica (1580-1625). Madrid: Arco Libros, pp. 501-562.

González de León, Félix (1844, ed. 1973): Noticia artística de todos los edificios públicos de esta muy noble ciudad de Sevilla. Sevilla: Gráficas del Sur.

\footnotetext{
48 Mide 32 x 45 x $11 \mathrm{~cm}$.

${ }^{49}$ Este objeto se ha reintegrado en la reciente restauración del retablo. El relieve mide $32 \times 45 \times 13 \mathrm{~cm}$.

${ }^{50}$ El tablero tiene unas dimensiones de $32 \times 98 \times 13 \mathrm{~cm}$.
} 
González Gómez, Juan M./Roda Peña, José (1992), Imaginería procesional de la Semana Santa de Sevilla. Sevilla: Universidad de Sevilla.

González Sánchez, Carlos A. (2012): “Entre Andrés y Francisco, libros son. La biblioteca de los Ocampo", en Calvario. Cuatro siglos de historia, Sevilla, 2012, pp. 54-59.

Guerrero Lovillo, José (1981), La Catedral de Sevilla. Madrid: Everest.

Halcón, Fátima (2000): "El retablo salomónico", en Halcón, Fátima/Herrera, Francisco J./ Recio, Álvaro: El retablo barroco sevillano. Sevilla: Universidad de Sevilla-Fundación El Monte, pp. 3-100.

Halcón, Fátima (2009 a y b): "El retablo sevillano de la primera mitad del siglo XVII" y "El triunfo de la columna salomónica”, en Halcón, Fátima/Herrera, Francisco J./Recio, Álvaro: El retablo sevillano desde los orígenes a la actualidad. Sevilla: Diputación Provincial de Sevilla-Fundación Real Maestranza de Caballería de Sevilla-Fundación Cajasol, pp. 129-202 y 205-288.

Hernández Díaz, José (1980): “Los Ocampo, imagineros giennenses del Siglo de Oro", en Boletín del Instituto de Estudios Giennenses, n 103, pp. 93-115.

Hernández Díaz, José (1984): "Retablos y esculturas”, en AA.VV.: La Catedral de Sevilla ..., ob. cit., pp. 221-320.

Hernández Díaz, José (1987a): Andrés de Ocampo (1555?-1623). Sevilla: Diputación Provincial de Sevilla.

Hernández Díaz, José (1987b), Juan Martínez Montañés (1568-1649). Sevilla: Ediciones Guadalquivir.

Herrera García, Francisco J. (2010): "El retablo sevillano en el tránsito de los siglos XVI al XVII: tracistas, modelos, tratados", en GILA MEDINA, L. (coord.), La escultura ..., ob. cit., pp. 309-330.

Illán, Magdalena/Valdivieso, Enrique (2005): Noticias artísticas sevillanas del Archivo Farfán Ramos. Siglos XVI-XVII y XVIII. Sevilla: Ediciones Guadalquivir.

Malo Lara, Lina (2003): “Aportación documental a los catálogos de Francisco de Ocampo y de Francisco Pacheco: sus intervenciones en el retablo mayor del convento de la Pasión de Sevilla”, en Laboratorio de Arte, n 16, pp. 417-425.

Malo Lara, Lina (2008-2009): “Juan Martínez Montañés, autor de la traza del primitivo retablo de Francisco de Rioja en el convento de las Teresas de Sevilla”, en Laboratorio de Arte, no 21, pp. 395-409.

Malo Lara, Lina (2015): La iglesia de San Alberto de Sevilla en el siglo XVII. Reconstrucción de un patrimonio artístico disperso o desparecido. Sevilla: Diputación Provincial de Sevilla.

Martín Macías, Antonio (1983): Francisco de Ocampo: maestro escultor (1579-1639). Sevilla: Gráficas del Sur.

Mata Torres, Josefa (2001): La rejería sevillana en el siglo XVI. Sevilla: Diputación Provincial de Sevilla.

Montoto de Sedas, Santiago (1948), La Catedral y el Alcázar de Sevilla. Madrid: Plus-Ultra.

Montoto de Sedas, Santiago (1955), "Descubrimiento del autor del retablo de la Encarnación de la Catedral de Sevilla", en Semana, Semana S.A., Madrid, nº 780, 1 de febrero de 1955, p. 25.

Morales Martínez, Alfredo J. (1985a): "La arquitectura de la Catedral de Sevilla en los siglos XVI, XVII y XVIII, en AA.VV.: La Catedral de Sevilla..., ob. cit., pp. 173-220.

Morales Martínez, Alfredo J. (1985b): "Artes aplicadas e industriales en la Catedral de Sevilla", en AA.VV.: La Catedral..., ob. cit., pp. 539-573.

Morales, Alfredo J., et al. (2004): Guía artística de Sevilla y su provincia, t. I. Sevilla: Fundación José Manuel Lara-Diputación de Sevilla.

Navarrete Prieto, Benito (1998): La pintura andaluza del siglo XVII y sus fuentes grabadas. Madrid: Fundación de Apoyo a la Historia del Arte Hispánico.

Navarrete Prieto, Benito (2005), "El Vignola del Colegio de Arquitectos de Valencia y sus retablos de traza sevillana: Juan Martínez Montañés", en Archivo Español de Arte, n 311, pp. 235-244.

Navarrete Prieto, Benito (2008): “La estampa como modelo en el Barroco andaluz”, en Morales Martínez, Alfredo J. (coord.): Actas del Congreso Internacional Andalucía Barroca. Arte, arquitectura y urbanismo, t. I. Sevilla: Junta de Andalucía. Conserjería de Cultura, pp. 159-168.

Otazu, Alfonso de (2008), El espíritu emprendedor de los vascos. Madrid: Sílex.

Pacheco, Francisco (1649, ed. 2001): Arte de la Pintura. Barcelona: Cátedra.

Palomero Páramo, Jesús M. (1982): "La influencia de los tratados arquitectónicos de Serlio y Palladio en los retablos de Martínez Montañés”, en AA.VV.: Homenaje al profesor Hernández Díaz, t. I. Sevilla: Universidad de Sevilla, pp. 503-525.

Palomero Páramo, Jesús M. (1983): El retablo sevillano del Renacimiento: analisis y evolucion (1560-1629). Sevilla: Diputación Provincial de Sevilla.

Pérez Embid, Florentino (1973): Pedro Millán y los orígenes de la escultura en Sevilla. Madrid: Instituto Diego Velázquez.

Quiles García, Fernando (2007): Teatro de la Gloria. El universo artístico de la Catedral de Sevilla en el Barroco. Sevilla: Diputación Provincial de Sevilla-Universidad Pablo de Olavide.

Ramos Sosa, Rafael (2010): “El Crucificado de Francisco de Ocampo en Santa Inés”, en Laboratorio de Arte, n 22, pp. 493-499.

Ramos Sosa, Rafael (2013): "Escultores y esculturas en la Antigua Capitanía General de Guatemala”, en Gila Medina, Lázaro (coord..): La consolidación..., ob. cit., pp. 281-300. 
Roda Peña, José (2013): "El triunfo del naturalismo en la escultura barroca sevillana”, en Gila Medina, Lázaro (coord.): La consolidación ..., ob. cit., pp. 143-178.

Roda Peña, José (2015): "Crucificados escultóricos sevillanos entre el Renacimiento y el primer naturalismo barroco", en En torno al réquiem de Tomas Luis de Victoria. Ensayos sobre arte, música y pensamiento. Sevilla: Ayuntamiento / ICAS, pp. 51-68.

Rodríguez Estévez, Juan C. (2007): “Los constructores de la Catedral”, en Jiménez Martín, A. (coord.): La catedral gótica de Sevilla: fundación y fábrica de la "obra nueva". Sevilla: Universidad de Sevilla.

Rodríguez Morales, Carlos (2010): "Presencia e influencia de la escultura andaluza en Canarias", en Gila Medina, L. (coord..), La escultura ..., ob. cit., pp. 459-472.

Santos y Olivera, Balbino (1930), Guía ilustrada de la catedral de Sevilla. Madrid: Talleres Voluntad.

Strauss, Walter L./Shimura, Tomoko (ed.) (1986): Netherlandish Artists: Cornelis Cort, en The Illustrated Bartsch (col.), t. LII. Nueva York: Avaris Books.

Tejada Vizuete, Francisco (1986): "Artes suntuarias en la Baja Extremadura en los siglos XVI y XVII", en Terrón Albarrán, Manuel (coord.): Historia de la Baja Extremadura, t. II. Badajoz: Real Academia de Extremadura de las Letras y las Artes, pp. 765-822.

Valdivieso, Enrique/Serrera, Juan Miguel (1985): Pintura sevillana del primer tercio del siglo XVII. Madrid: Consejo Superior de Investigaciones Científicas.

Vila Vilar, Enriqueta (2002): "Una amplia nómina de los nombres del comercio sevillano del siglo XVII", en Minervae Baeticae. Boletín de la Real Academia Sevillana de Buenas Letras, n 30, pp. 139-191.

Vila Vilar, Enriqueta/Kuethe, Lourdes (2006): "La idea de nobleza y el 'Más Allá': advocaciones religiosas en los testamentos", en Minervae Baeticae. Boletín de la Real Academia Sevillana de Buenas Letras, no 34, pp. 213-233.

Vila Vilar, Enriqueta/Lohmann Villena, Guillermo (2003), Familia, linajes y negocios entre Sevilla y las Indias. Los Almonte. Madrid: Fundación Mapfre Tavera.

Villar Movellán, Alberto (1977): La Catedral de Sevilla. Guía oficial. Sevilla: Cabildo de la Iglesia Metropolitana y Patriarcal.

Fecha de recepción: 09-VI-2015

Fecha de aceptación: 29-X-2015 